\title{
IMPLEMENTASI PENGHAPUSAN BARANG MILIK DAERAH RUSAK BERAT PADA PEMERINTAH KOTA MATARAM
}

\author{
Putu Wawan Martina, Titiek Herwanti, \& Hermanto \\ Universitas Mataram, Indonesia \\ Email: putuwawan99@gmail.com
}

\begin{abstract}
Abstrak: Implementasi Penghapusan Barang Milik Daerah Rusak Berat Pada Pemerintah Kota Mataram. Riset ini memiliki tujuan untuk mengetahui implementasi penghapusan BMD rusak berat pada Pemerintah Kota Mataram berdasarkan Permendagri No. 19 Tahun 2016. Proses penghapusan BMD berdasarkan Permendagri No. 19 Tahun 2016 mengalami perubahan mekanisme jika dibandingkan dengan aturan sebelumnya. Berdasarkan hasil riset menunjukkan bahwa proses penghapusan BMD rusak berat pada Pemerintah Kota Mataram pelaksanaannya masih dipusatkan pada Badan Pengelolaan Keuangan dan Aset (BPKAD) Kota Mataram selaku leading sector pengelolaan BMD. Kendala utama yang menjadi penghambat adalah ketidaklengkapan dokumen serta ketidakjelasan fisik barang yang diusulkan untuk dihapuskan. Hal tersebut disebabkan karena beberapa hal yaitu proses hibah di masa lalu yang tidak disertai dokumen, pengawasan yang belum maksimal terhadap BMD rusak berat, seringnya terjadi perpindahan kantor Satuan Kerja Perangkat Daerah (SKPD), Sumber Daya Manusia (SDM) yang belum memadai, serta tidak adanya Standar Operasional Prosedur (SOP) tentang penghapusan BMD.
\end{abstract}

Kata kunci: BMD Rusak Berat, Penghapusan, Pengelolaan BMD

Abstract: Implementation of Heavy Damaged Regional Property Disposal in Mataram City Government. This study aimed to determine and analyse the disposal process of Regional Property or known as Barang Milik Daerah (BMD), which were heavily damaged, in Mataram City Government in accordance to Ministry of Home Affairs Regulation Number 19 Year 2016. The new regulation regarding the disposal process of BMD changed the required procedures, compared to the previous regulations. This study found that the disposal process of heavily damaged BMD in the Mataram City Government was centered on the BPKAD Kota Mataram as the leading sector of BMD management. The main obstacle of disposal process is incomplete documents and physical vagueness of goods proposed to be disposed. These problems were caused by several things; the grant process in the past which were not accompanied by proper documents, unreliable supervision for heavily damaged BMD, frequent changes of SKPD office site, unskilled human resources, and the lack of a Standard Operational Procedure (SOP) for disposal process.

Keywords: Heavy Damaged Regional Property, Disposal, Regional Property Management

\section{PENDAHULUAN}

Tata kelola pemerintahan yang baik merupakan suatu prinsip pokok yang harus diberlakukan di seluruh Negara Indonesia. Perubahan-perubahan dalam sistem pemerintahan yang terjadi mulai dari masa orde lama hingga era reformasi telah meninggalkan jejak pada tata kelola pemerintahan yang ada saat ini. Jejak-jejak yang ditinggalkan pada setiap masa dalam sistem tata kelola pemerintah diharapkan adalah dampak yang baik. Namun satu hal 
yang pasti di dalam menciptakan tata kelola yang baik, adalah diperlukannya penguatan dalam sistem dan kelembagaan dengan berdasarkan pada perundang-undangan yang berlaku.

Penerapan otonomi daerah melalui Undang-undang (UU) No. 32 tahun 2004 yang kemudian diubah dengan UU No. 23 tahun 2014 tentang Pemerintahan Daerah ditambah lagi dengan kaidah Good Government Governance yang selalu digaung-gaungkan belakangan ini dapat dianggap sebagai salah satu upaya untuk meningkatkan tata kelola pemerintahan tersebut. Era otonomi daerah menuntut pemerintah daerah untuk menggali sumbersumber pendapatan daerah yang baru secara mandiri. Batubara (2006) menyatakan bahwa salah satu point yang menjadi karakteristik pelaksanaan Good Governance yaitu Efficiency and Effectiveness di mana pengelolaan sumber daya publik dilakukan secara berdaya guna (efisien) dan berhasil guna (efektif). Upaya dalam rangka melakukan efisiensi pada pengelolaan keuangan pemerintah daerah dapat dilakukan dengan mengoptimalisasi pada pengelolaan barang milik daerahnya.

Diterbitkannya Peraturan Pemerintah No. 6 tahun 2006 tentang Pengelolaan Barang Milik Negara/Daerah yang kemudian disusul dengan Permendagri No. 17 tahun 2007 sebagai Pedoman Teknis Pengelolaan Barang Milik Daerah dapat dikatakan sebagai tonggak awal dari tertib pengelolaan barang milik daerah (BMD) pada era otonomi daerah. Dalam kerangka otonomi daerah, peranan pengelolaan BMD menjadi sangat vital karena di dalamnya diperlukan perencanaan yang matang mulai dari rencana pengadaan, pemanfaatan, sampai dengan penghapusan (Shabrina, 2014).

Pelaksanaan tertib pengelolaan BMD memang masih menyisakan sejumlah permasalahan. Beberapa permasalahan terkait manajemen aset tetap khususnya negara berkembang antara lain manajemen aset publik yang terpecah-pecah dengan kewenangan yang tumpang tindih, inefisiensi ekonomi aset publik, informasi mengenai aset yang tidak komprehensif serta transparansi dan akuntabilitas manajemen aset yang masih kurang (Hariyono, 2007).

Penerapan Standar Akuntansi Pemerintahan (SAP) berbasis akrual pada pemerintah daerah melalui PP No. 71 tahun 2011 dan Permendagri No. 64 tahun 2013 secara tidak langsung mengamanatkan agar permasalahan pengelolaan BMD harus segera teratasi. Tujuan dikeluarkannya aturan ini menurut Langelo, Saerang, \& Alexander (2015) yakni digunakan untuk menghasilkan suatu laporan keuangan yang andal dan dapat dijadikan pijakan dalam pengambilan keputusan di mana pemerintah pusat/daerah wajib menyajikan laporan keuangan agar tercipta akuntabilitas dan transparansi dari pengelolaan keuangan tersebut. Oleh karena itu, tertibnya pengelolaan BMD pada Pemerintah Daerah menjadi hal yang sangat penting agar nilai akuntabilitas dan transparansi pada pengelolaan keuangan pemerintah daerah dapat tercapai secara maksimal.

Pada Ikhtisar Hasil Pemeriksaan Semester I BPK-RI tahun 2015 diungkapkan beberapa temuan yang menjadi permasalahan pada pengelolaan BMD yaitu di antaranya aset tetap tidak diketahui keberadaannya atau dikuasai pihak lain, tidak 
didukung dengan bukti kepemilikan, penghapusan dan penyusutannya tidak sesuai dengan ketentuan. Dari beberapa permasalahan tersebut, permasalahan penghapusan menjadi salah satu yang harus cepat diatasi. Hal ini juga diungkapkan Hamdani (2015) bahwa salah satu titik kritis pengelolaan BMD (aset tetap) dalam rangka akuntansi berbasis akrual yakni penghapusan BMD yang sudah rusak berat dan tidak berfungsi dalam operasional SKPD.

Permasalahan dalam penghapusan BMD ini muncul jika proses penghapusannya tidak segera dilakukan dan menyebabkan terjadinya penumpukan BMD rusak berat. Fransiska (2014) mengungkapkan bahwa permasalahan penghapusan barang-barang milik daerah tidak dapat dianggap ringan karena jika tidak diperhatikan secara serius akan timbul kondisi di mana barang yang belum dihapuskan tidak dapat digunakan atau bahkan tidak memberikan kontribusi dan secara tidak langsung hanya membebani biaya pemeliharaannya.
Kondisi-kondisi seperti inilah yang disinyalir terjadi pada pengelolaan BMD pada Pemerintah Kota Mataram. Berdasarkan tabel 1 dapat terlihat bahwa nilai aset lainlain yang masih tercatat sampai dengan tahun 2015 adalah sebesar Rp34.224.704.495. Aset lain-lain menurut Permendagri 64 Tahun 2013 didefinisikan sebagai aset tetap yang dimaksudkan untuk dihentikan dari penggunaan aktif pemerintah. Hal ini dapat disebabkan karena rusak berat, usang, dan/atau aset tetap yang tidak digunakan karena sedang menunggu proses pemindahtanganan. Dengan kata lain bahwa aset lain-lain juga merupakan barang milik daerah (BMD) yang sudah tidak dapat digunakan/rusak berat. Dari data yang tersaji pada tabel 1 juga dapat diasumsikan bahwa masih terdapat permasalahan dimana sampai dengan 2015, Pemerintah Kota Mataram belum melakukan proses penghapusan secara teratur terhadap barang-barang yang rusak berat senilai Rp34.224.704.495 sehingga mengakibatkan terjadinya penumpukan. Walaupun

Tabel 1. Nilai Aset Tetap dan Aset Lainnya pada Pemerintah Kota Mataram tahun 2015

\begin{tabular}{lr}
\hline \multicolumn{1}{c}{ Uraian } & \multicolumn{1}{c}{ Nilai } \\
\hline \multicolumn{1}{c}{ ASET TETAP } & \\
\hline Tanah & 887.656 .346 .539 \\
Peralatan dan Mesin & 376.846 .388 .849 \\
Gedung dan Bangunan & 820.598 .537 .491 \\
Jalan, Jaringan, dan Irigasi & 501.810 .217 .034 \\
Aset Tetap Lainnya & 41.638 .591 .386 \\
KDP & 477.824 .000 \\
Jumlah Aset Tetap & $\mathbf{2 . 6 2 9 . 0 2 7 . 9 0 5 . 3 0 1}$ \\
& \\
ASET LAINNYA & 231.128 .730 .00 \\
\hline Kemitraan Pihak Ketiga & 464.715 .800 \\
Aset Tidak Berwujud & 34.224 .704 .495 \\
Aset Lain-lain & $\mathbf{2 6 5 . 8 1 8 . 1 5 0 . 2 9 5}$ \\
Jumlah Aset Lainnya &
\end{tabular}

Sumber: LHP BPK-RI terhadap LKPD Kota Mataram Tahun 2015 (data diolah) 
permasalahan penghapusan BMD ini masih dianggap tidak material oleh BPK-RI sehingga tidak mempengaruhi opini Wajar Tanpa Pengecualian (WTP) yang diperoleh Pemerintah Kota Mataram, namun patut menjadi catatan karena jika dibiarkan berlarut-larut dapat menjadi suatu hal yang merugikan di kemudian hari.

Penghapusan BMD memang tidak semudah yang dibayangkan masyarakat pada umumnya. Banyak pihak-pihak yang terlibat di dalam proses penghapusan BMD. Di samping itu kriteria barang-barang yang akan dihapus juga harus ditentukan secara spesifik untuk menghindari adanya kerugian negara. Permendagri No. 19 Tahun 2016 sebagai aturan terbaru mengenai pengelolaan barang milik daerah telah mengatur mekanisme penghapusan BMD ini. Seperti yang diungkapkan Aziz (2015) bahwa Penghapusan penghapusan barang milik daerah harus melalui mekanisme yang panjang dan harus sesuai dengan peraturan perundang-undangan yang berlaku. Meskipun demikian demi tertib pengelolaan barang milik daerah, proses ini harus tetap dilakukan.

\section{METODE}

Mengingat tujuan dari penelitian ini yaitu untuk menganalisis secara rinci implementasi dan proses penghapusan barang milik daerah (BMD) pada Pemerintah Kota Mataram maka metode penelitian yang akan digunakan adalah metode penelitian kualitatif dengan pendekatan studi kasus. Menurut Blaikie (2000), terdapat lima klasifikasi atas studi kasus yang dapat digunakan yaitu: configurative ideographic studies, disciplined comparative studies, heuristic case studies, plausibility probes, dan crucial case studies. Sedangkan Yin (1994) dalam Asmony (2015) menyatakan bahwa dalam hal desain penelitian studi kasus terdapat empat desain yaitu single case (holistic), single case (embedded), multiple case (holistic), dan multiple case (embedded). Pada penelitian ini klasifikasi atas studi kasusnya lebih mendekati pada disciplined comparative studies dengan desain single case (holistic). Disciplined comparative studies sesuai namanya bertujuan untuk membandingkan kasus yang dipelajari dengan teori yang mapan (Kamayanti, 2016). Kasus yang akan diteliti dalam penelitian ini yaitu mengenai proses penghapusan barang milik daerah berdasarkan Permendagri No. 19 Tahun 2016. Tipe desain penelitian ini menggunakan single case (holistic) karena menggunakan satu unit analisis yaitu BPKAD Kota Mataram selaku leading sector dalam pengelolaan barang milik daerah Kota Mataram dengan satu objek kasus yaitu penghapusan barang milik daerah (BMD) rusak berat.

Pengumpulan data dilakukan melalui wawancara semiterstruktur, observasi partisipatif dan dokumentasi. Proses wawancara dilakukan terhadap Kepala Bidang Aset BPKAD Kota Mataram, Kepala Subbidang Penatausahaan Aset BPKAD Kota Mataram, Kepala Subbidang Pendayagunaan Aset BPKAD Kota Mataram, Kepala Bagian Umum Sekretariat Daerah Kota Mataram dan Pengurus Barang SKPD di Pemerintah Kota Mataram. Prosedur analisis data yang digunakan adalah model analisa data kualitatif secara interaktif dari Miles dan Huberman (1992) yang terdiri dari reduksi data, penyajian data dan penarikan 
kesimpulan yang dilakukan secara bersamaan.

\section{HASIL DAN PEMBAHASAN}

Sebagai bagian dari ruang lingkup pengelolaan Barang Milik Daerah (BMD), proses penghapusan BMD memiliki peranan yang tidak kalah pentingnya guna mewujudkan tata kelola BMD yang professional yang mampu menghasilkan informasi yang lengkap, relevan dan dapat dipertanggungjawabkan. Dari sisi pertanggungjawaban, Barang Milik Daerah bukanlah barang untuk kepentingan pribadi melainkan barang publik karena sebagian besar sumber perolehannya berasal dari keuangan daerah dan dipergunakan sebagai sarana dan prasarana operasional para aparatur pemerintah daerah dalam memberikan pelayanan kepada masyarakat. Oleh karena hal tersebut, dalam mengelola BMD yang dimulai dari perencanaan, pengadaan, penggunaan sampai dengan penghapusan BMD harus dilakukan dengan cermat dan penuh kehati-hatian.

Tidak dapat dipungkiri, seiring berjalannya waktu, BMD yang dipergunakan secara terus menerus akan mengalami penurunan secara fisik maupun fungsi. Ada kalanya hal tersebut dapat diantisipasi dengan memberikan pemeliharaan yang teratur. Namun, jika kegiatan pemeliharaan dinilai sudah tidak memungkinkan untuk dilakukan karena pertimbangan biaya maupun manfaat yang tidak sesuai, maka BMD tersebut akan dihentikan penggunaannya dan dikondisikan rusak berat. Sebuah BMD yang telah dikondisikan rusak berat, penanganannya tidak serta merta hanya ditempatkan pada ruangan khusus/gudang melainkan harus segera dilakukan tindakan secara tepat yang berujung pada proses penghapusan BMD. Jika tidak demikian maka penumpukan BMD rusak berat tidak dapat dihindari yang memungkinkan untuk menimbulkan permasalahan-permasalahan yang lain.

Pemaparan dari hasil penelitian implementasi penghapusan Barang Milik Daerah (BMD) dengan kondisi rusak berat pada Pemerintah Kota Mataram dilakukan peneliti dengan membandingkannya dengan teori, regulasi yang berlaku, dan hasil dari beberapa penelitian terdahulu. Peneliti telah melakukan pembagian ke dalam 3 (tiga) tema/bagian utama untuk mendapatkan pemahaman yang lebih komprehensif mengenai proses penghapusan BMD dengan kondisi rusak berat pada Pemerintah Kota Mataram yaitu sebagai berikut:

Gambaran Umum Pengelolaan BMD Pada Pemerintah Kota Mataram

Pada Pemerintah Kota Mataram, BMD dengan kondisi rusak berat yang menumpuk merupakan BMD yang diperoleh sejak awal terbentuknya Pemerintah Kota Mataram sampai dengan saat ini dan belum mengalami proses penghapusan. Kota Mataram terbentuk pada tahun 1993 sebagai hasil pemekaran dari Kabupaten Lombok Barat berdasarkan Undang-Undang No. 4 Tahun 1993 tentang Pembentukan Kotamadya Dati II Mataram. Sebagai tindak lanjut dari proses pemekaran tersebut, selanjutnya dibuatkan berita acara penyerahan aset Pemerintah Kabupaten Lombok Barat sebagai daerah induk kepada Pemerintah Kota Mataram. Berita Acara Serah Terima (BAST) BMD tersebut merupakan suatu hal yang sangat penting bagi Pemerintah Kota Mataram dan 
Tabel 2. BMD Rusak Berat pada Pemerintah Kota Mataram Berdasarkan Sensus Tahun 2001

\begin{tabular}{clr}
\hline No. & \multicolumn{1}{c}{ Nama BMD } & \multicolumn{1}{c}{ Nilai (Rp) } \\
\hline 1. & Tanah & 1.075 .886 .067 \\
2. & Peralatan dan Mesin & 6.530 .785 .420 \\
3. & Gedung dan Bangunan & 350.000 \\
4. & Jalan, Jaringan dan Irigasi & 79.259 .700 \\
5. & Aset Tetap Lainnya & 7.686 .281 .187 \\
\hline
\end{tabular}

Sumber: BPKAD Kota Mataram (data diolah)

menjadi modal awal dalam menjalankan pemerintahannya.

Pemerintah Kota Mataram melakukan kegiatan sensus BMD sebagai langkah awal dalam menertibkan pengelolaan BMD. Sensus BMD pada Pemerintah Kota Mataram pertama kali dilakukan pada tahun 2001. Bagian Umum Sekretariat Daerah Kota Mataram yang pada saat itu sesuai dengan Kepmendagri No. 11 Tahun 2001 bertindak selaku Pembantu Kuasa Barang melakukan sensus BMD dengan bekerjasama dengan pihak BPKP Perwakilan NTB. Hal tersebut sesuai dengan penjelasan Kepala Bidang Aset BPKAD Kota Mataram, yaitu sebagai berikut:

“...sensus BMD pertama kali kita lakukan pada tahun 2001 bekerjasama dengan BPKP perwakilan NTB. Pada saat itu, pengelolaan aset masih dilaksakan oleh Bagian Umum Setda Kota Mataram. Dari hasil sensus tersebut kita memberikan penilaian terhadap aset-aset hasil serah terima dari Lombok Barat berdasarkan dokumen penyerahan Personil, Pendanaan, Sarana dan Prasarana, dan Dokumen (P3D). Memang di dokumen itu semua aset yang menjadi objek serah terima tidak memiliki nilai. Jadi untuk penyusunan neraca awal semua aset tersebut harus dinilai ulang"
Kegiatan sensus dimaksudkan untuk menginventarisasi dan melakukan pendataan ulang terhadap BMD hasil serah terima dari Pemkab Lombok Barat ditambah dengan BMD hasil pengadaan yang bersumber dari APBD. Selain untuk memperoleh data yang lebih aktual mengenai kuantitas BMD yang dimiliki oleh Pemerintah Kota Mataram, kegiatan tersebut juga untuk melakukan penilaian kembali terhadap BMD hasil serah terima yang belum memiliki nilai perolehan. Berdasarkan data hasil sensus, kemudian diketahui nilai total BMD dengan kondisi rusak berat yang dimiliki Pemerintah Kota Mataram sesuai dengan tabel 2 adalah sebesar Rp 7.686.281.187.

Selama koordinator pelaksanaan pengelolaan BMD pada Pemerintah Kota Mataram menjadi tanggungjawab dari Bagian Umum Sekretariat Daerah Kota Mataram, kegiatan penghapusan terhadap BMD rusak berat belum dapat diselesaikan secara tuntas. Besarnya beban kerja yang menjadi tanggungjawab Bagian Umum Setda Kota Mataram membuat kegiatan penghapusan BMD rusak berat belum menjadi prioritas untuk segera dituntaskan. Hal tersebut dapat terlihat berdasarkan penjelasan dari Kepala Bagian Umum Setda Kota Mataram sebagai berikut: 
“...Bukannya tidak ditindak lanjuti, sejak tahun 2011 kita sudah berupaya untuk segera menindaklanjuti. Kita sudah bersurat ke skpd mengenai kegiatan penghapusan, kita juga sudah merekap usulan dari skpd tersebut baik secara manual maupun sistem. Dulu bagian umum selain jadi pembantu pengelola barang kerjaan kita kan banyak, kita juga mengurus rumah tangga pimpinan, rumah tangga pak wali juga pak wakil, juga kita melakukan semua pemeliharaan gedung kantor ini baik gedung utara maupun selatan belum lagi pendopo walikota, rumah dinas wakil dan sekda. Kegiatan itu semua ada pada satu subbag perlengkapan. Permasalahan aset yang lain juga masih banyak, masalah data belum fix, trus ada tanah yang nilainya nol dan belum bersertifikat, kemudian dobel catat kendaraan, ada kendaraan yang dipegang pensiunan, kegiatan ruislag. Pokoknya kegiatannya banyak dan kita belum bisa fokus untuk kegiatan penghapusan tersebut."

Besarnya beban kerja yang diemban oleh Bagian Umum Setda Kota Mataram selaku Pembantu Pengelola Barang mulai berkurang sejak terbentuknya Badan Pengelolaan Keuangan dan Aset (BPKAD) Kota Mataram pada tanggal 14 November 2013. BPKAD Kota Mataram dibentuk berdasarkan Perda Kota Mataram Nomor 8 tahun 2013 tentang Pembentukan Susunan Organisasi Perangkat Daerah Kota Mataram. Dengan terbentuknya BPKAD Kota Mataram, fungsi tanggung jawab pengelolaan BMD pada Pemerintah Kota Mataram berpindah ke Bidang Aset BPKAD Kota Mataram. Selain menjadi lebih fokus untuk melakukan kegiatan pengelolaan BMD pada Pemerintah Kota Mataram, dengan terbentuknya SKPD/OPD setingkat Badan untuk menjadi Pembantu Pengelola Barang memberikan rentang koordinasi yang lebih luas untuk menyelesaikan permasalahanpermasalahan dalam pengelolaan BMD pada Pemerintah Kota Mataram khususnya penyelesaian penghapusan BMD rusak berat. Implementasi Penghapusan BMD Rusak Berat Pada Pemerintah Kota Mataram

Pelimpahan wewenang dan tanggungjawab pengelolaan BMD dari Bagian Umum Setda Kota Mataram kepada BPKAD Kota Mataram diiringi juga dengan berbagai macam permasalahannya yang salah satunya yakni belum tuntasnya penghapusan BMD rusak berat. Akibatnya, nilai BMD rusak berat terus mengalami peningkatan menjadi $\mathrm{Rp}$. 36.624.708.803 pada tahun 2016 dengan jumlah 8.241 item BMD. BPKAD Kota Mataram melalui Bidang Asetnya terus berupaya untuk menuntaskan penghapusan BMD rusak berat tersebut. Kurangnya regulasi yang mengatur secara teknis tentang penghapusan BMD rusak berat menjadi sebuah tantangan yang dihadapi. Dalam ruang lingkup pengelolaan BMD, Pemerintah Kota Mataram telah memiliki Peraturan Daerah (Perda) tentang Pengelolaan BMD melalui Perda No. 17 Tahun 2011. Namun berkaitan dengan kegiatan penghapusan BMD, sejak awal belum ada regulasi yang mengatur secara mendetail mengenai penghapusan BMD khususnya dengan kondisi rusak berat.

Terbitnya Peraturan Menteri Dalam Negeri (Permendagri) Nomor 19 Tahun 2016 sebagai acuan terkini dalam penyelenggaraan pengelolaan BMD seperti 
memberikan harapan baru didalam penyelesaian kegiatan penghapusan BMD rusak berat pada Pemerintah Kota Mataram. Terdapat perbedaan yang mendasar antara proses penghapusan BMD rusak berat berdasarkan Permendagri No. 19 Tahun 2016 dengan aturan sebelumnya. Berdasarkan aturan terbaru, proses penghapusan BMD rusak berat merupakan tindakan akhir dari proses pemindahtangan atau pemusnahan BMD. Sedangkan menurut aturan sebelumnya, proses penghapusan BMD merupakan tindakan awal sebelum dilakukan proses pemindahtangan atau pemusnahan $B M D$, baik itu BMD rusak berat maupun BMD yang masih dalam kondisi baik. Hal ini sesuai dengan penjelasan dari Kasubbid Penatausahaan Aset BPKAD Kota Mataram sebagai berikut:

"kalau penghapusan di permendagri 19 penghapusan paling akhir, sementara di permendagri 17, penghapusan paling depan, kita cenderung menggunakan permendagri 19 yaitu yang terbaru, sementara dari efisiensi juga lebih tepat. Contohnya gini, misalnya ada penjualan nih, kalau menggunakan permendagri 17, kita sudah pengumuman nih mau penjualan mau pelelangan, kita hapuskan eh Taunya gak laku, repot kan memasukkan lagi. Tapi dengan mekanisme yang baru dia lebih fleksibel kita sudah melakukan penjualan, jadi mana yang laku, mana yang nilai yang dimusnahkan itulah yang di hapuskan"

Penghapusan BMD berdasarkan Permendagri No. 19 Tahun 2016 menyajikan tahapan-tahapan yang lebih realistis terutama jika berkaitan dengan penghapusan BMD rusak berat. Dengan nilai total BMD rusak berat yang dimiliki Pemerintah Kota Mataram sebesar Rp. 36.624.708.803, jika mengacu pada aturan yang lama maka akan diperlukan persetujuan dari DPRD untuk mengeksekusi seluruh BMD rusak berat tersebut. Sedangkan dengan aturan yang baru, persetujuan DPRD diperlukan jika dari total BMD rusak berat tersebut, terdapat BMD selain tanah dan/atau bangunan yang akan dipindahtangankan dengan nilai diatas Rp 5 Milyar setelah dilakukan penilaian ulang. Hal ini menunjukkan bahwa terdapat pemotongan alur birokrasi pada proses penghapusan BMD rusak berat sehingga diharapkan prosesnya menjadi lebih cepat.

Atas dasar Permendagri No. 19 Tahun 2016, BPKAD Kota Mataram selaku leading sector pengelolaan BMD pada Pemerintah Kota Mataram melakukan tahapan-tahapan penghapusan BMD sebagai upaya untuk mengatasi permasalahan penumpukkan BMD rusak berat. Tahap awal pelaksanaan proses Penghapusan BMD pada Pemerintah Kota Mataram dimulai dengan membentuk panitia penghapusan BMD. Kepanitiaan tersebut dibentuk melalui Surat Keputusan dari Walikota Mataram yang susunan anggotanya terdiri dari unsur-unsur dari BPKAD Kota Mataram, unsur dari Inspektorat Kota Mataram, unsur dari Bagian Hukum Setda Kota Mataram serta unsur dari SKPD yang bersangkutan yang mengajukan usulan kegiatan. Panitia penghapusan yang dibentuk, sekaligus juga sebagai panitia peneliti/pemeriksa. Tugas tersebut antara lain melakukan uji fisik dengan meneliti kondisi barang-barang yang diajukan untuk dihapuskan, baik dari kepemilikan, 
administrasi, pengguna, kerusakan maupun data lainnya yang dipandang perlu. Tahapan selanjutnya yang dilalui sesuai dengan penjelasan Kabid Aset pada BPKAD Kota Mataram adalah sebagai berikut:

1. Sekretaris Daerah Kota Mataram sebagai Pengelola Barang melalui BPKAD Kota Mataram selaku koordinator pengelolaan BMD membuat surat pemberitahuan kegiatan penghapusan BMD kepada semua SKPD lingkup Pemerintah Kota Mataram.

2. Atas dasar surat pemberitahuan tersebut, Kepala SKPD selaku Pengguna Barang mengajukan Surat Permohonan Penghapusan BMD kepada Sekretaris Daerah Kota Mataram melalui BPKAD Kota Mataram.

3. Panitia penghapusan BMD Kota Mataram melakukan penelitian lapangan, uji fisik sekaligus pemilahan terhadap BMD yang ditaksir masih memiliki nilai ekonomis dan yang sudah tidak memiliki nilai ekonomis. Hasil dari penelitian lapangan dituangkan ke dalam Berita Acara.

4. Untuk BMD yang ditaksir masih memiliki nilai ekonomis. Panitia Penghapusan BMD akan menindaklanjutinya melalui proses pemindahtanganan BMD. Proses pemindahtanganan BMD dapat berupa penjualan maupun hibah.

5. Jika pemindahtanganan dilakukan melalui mekanisme penjualan/lelang maka .terlebih dahulu dilakukan proses penilaian BMD untuk memperoleh nilai wajar BMD dan menjadi nilai limit lelang. Penilaian BMD dapat dilakukan oleh Kantor Pelayanan Kekayaan Negara dan Lelang (KPKNL) selaku Penilai Pemerintah atau Kantor Jasa Penilai Publik (KJPP) selaku penilai publik yang ditetapkan oleh Walikota Mataram.

6. Setelah proses penjualan/lelang, terhadap BMD yang berhasil terjual/dilelang hasilnya disetorkan ke rekening kas umum daerah dan dibuat Berita Acara Serah Terima (BAST) BMD. Sedangkan untuk BMD yang tidak berhasil terjual/tidak memiliki peminat dalam lelang, maka ditindaklanjuti dengan mekanisme hibah atau pemusnahan BMD.

7. Jika pemindahtangan dilakukan dengan mekanisme hibah maka dibuatkan Naskah Hibah dan Berita Acara Serah Terima (BAST) BMD.

8. Untuk BMD yang ditaksir sudah tidak memiliki nilai ekonomis. Panitia Penghapusan BMD akan menindaklanjutinya dengan mekanisme pemusnahan BMD. Atas pemusnahan BMD tersebut dibuatkan Berita Acara Pemusnahan BMD.

9. Setelah proses selesai, Walikota Mataram menerbitkan Surat Keputusan Penghapusan BMD berdasarkan Berita Acara Serah Terima (BAST) BMD jika proses dilakukan dengan mekanisme pemindahtanganan dan Berita Acara Pemusnahan BMD jika proses dilakukan dengan mekanisme pemusnahan.

10. Berdasarkan Surat Keputusan Penghapusan BMD tersebut, BMD dihapuskan dari Daftar Barang Milik Daerah.

Berdasarkan tahapan-tahapan proses penghapusan BMD pada Pada Pemerintah Kota Mataram yang sedang dilakukan maka kegiatan penghapusan BMD rusak berat masih dipusatkan pada Pengelola Barang melalui BPKAD Kota Mataram dalam 
kapasitasnya sebagai Penatausaha BMD pada Pemerintah Kota Mataram. Jika mengacu pada aturan, mekanisme yang ditempuh tersebut bukan sesuatu yang menyimpang. Namun jika dilihat dari sudut pandang konsep tata kelola yang baik, mekanisme tersebut belum mengakomodir prinsip efektifitas dan efisiensi. Kegiatan penghapusan BMD rusak berat masih memiliki karakter top-down sehingga SKPD selaku pengguna barang bersifat pasif dan hanya menunggu inisiasi/perintah dari BPKAD Kota Mataram. Waktu pelaksanaan kegiatan menjadi lebih lama karena diperlukan waktu tambahan untuk mengumpulkan data usulan BMD rusak berat yang akan dihapuskan dari semua SKPD. Hasil temuan data lapangan yang diperoleh peneliti mengungkapkan bahwa progres kegiatan penghapusan BMD rusak berat masih berada dalam tahapan uji fisik terhadap BMD rusak berat yang diusulkan untuk dihapuskan.

Pada Permendagri Nomor 19 Tahun 2016 sebagai acuan pengelolaan BMD, telah dilakukan pemisahan fungsi-fungsi pengelolaan pada tataran Pengelola Barang maupun Pengguna Barang. Kegiatankegiatan seperti proses pemindahtanganan BMD, pemusnahan BMD maupun penghapusan BMD tidak hanya dilakukan pada tataran Pengelola Barang, tetapi juga dapat dilakukan pada tataran SKPD/OPD selaku Pengguna Barang. Kegiatan penghapusan BMD dipisahkan menjadi 3 (tiga) bagian yaitu penghapusan pada barang pengelola, penghapusan pada barang pengguna, dan penghapusan pada barang milik daerah. Hal positif yang dapat diperoleh jika penghapusan BMD rusak berat dilaksanakan pada tingkat Pengguna Barang yakni BPKAD Kota Mataram selaku koordinator pengelolaan BMD dapat memberikan skala prioritas terhadap semua usulan SKPD untuk penghapusan BMD rusak berat. SKPD yang memiliki tingkat permasalahan lebih sedikit dapat diprioritaskan lebih dahulu. Dengan demikian progres kegiatan penghapusan BMD rusak berat dapat dengan mudah diukur dan menjadi acuan kinerja bagi panitia penghapusan BMD.

Kendala-Kendala Proses Penghapusan BMD Rusak Berat Pada Pemerintah Kota Mataram Dalam pelaksanaan kegiatan penghapusan BMD rusak berat yang dilakukan oleh BPKAD Kota Mataram terdapat beberapa permasalahan yang menjadi hambatan. Permasalahan yang menjadi hambatan utama adalah ketidaklengkapan dokumen kepemilikan/ perolehan dan ketidakjelasan fisik dari BMD rusak berat yang diusulkan untuk dihapuskan tersebut. Jika ditinjau dari sejarah pengelolaan BMD pada Pemerintah Kota Mataram, permasalahan-permasalahan tersebut muncul akibat kesemrawutan pelaksanaan pengelolaan BMD pada masa lalu yang terakumulasi hingga sekarang. Hal tersebut sesuai dengan hasil penelitian Hasni (2012) yang menyatakan bahwa pelaksanaan penghapusan BMD pada Bagian Aset Setda Kabupaten Lombok Tengah belum optimal karena penatausahaan aset daerah tidak tertib dan informasi mengenai sejarah aset tidak utuh sehingga proses penghapusan aset daerah tidak berjalan optimal. Hasil riset ini mengungkapkan bahwa penyebab-penyebab dari ketidaklengkapan dokumen 
kepemilikan/perolehan maupun ketidakjelasan fisik dari BMD rusak berat tersebut adalah sebagai berikut.

Pertama, proses hibah yang tidak disertai dokumen kepemilikan. Tidak adanya dokumen kepemilikan terhadap barangbarang hasil hibah di masa lampau yang sekarang sudah dalam kondisi rusak berat menjadi salah satu kendala di dalam proses penghapusannya. Sebagai kota hasil pemekaran dari Kab. Lombok Barat seperti yang telah dijelaskan sebelumnya, Pemerintah Kota Mataram pada awalnya mendapatkan BMD sebagai modal menjalankan pemerintahannya dalam bentuk hibah. Dokumen hibah tersebut tertuang melalui Berita Acara Penyerahan Aset dari Pemkab. Lombok Barat kepada Pemkot. Mataram. Hal tersebut tertuang pada penjelasan dari Kasubbid Pendayagunaan Aset pada BPKAD Kota Mataram sebagai berikut:

"Secara fisiknya, secara faktualnya memang ada, tetapi pada dasarnya semua BMD itu pasti diketahui asal usulnya, tetapi dokumennya yang tidak diketemukan terutama pada objek BMD yang didapatkan, diperoleh dari pemekaran kota mataram tahun 1993, berdasarkan UU No. 04 tahun 1993 tentang pembentukan daerah tingkat ॥ Kodya Mataram. Kita khususnya untuk $B M D$ yang bukan berasal dari APBD tetapi yang berasal dari perolehan lainnya yang sah yang kita mempunyai kendala terkait legalitas /alas hak kepemilikan kita sehingga kita sangat kesulitan untuk melakukan pemindahtangan atau penghapusan karena dokumen barang milik daerah itu ada yang belum diserahkan atau memang sudah diserahkan tetapi tidak diketemukan tempatnya itu yang menjadi kendala kita"

Hibah menurut Permendagri No. 19 Tahun 2016 didefinisikan sebagai pengalihan kepemilikan barang dari pemerintah pusat kepada pemerintah daerah, antar pemerintah daerah, atau pemerintah daerah kepada pihak lain tanpa memperoleh imbalan. Dalam ruang lingkup pengelolaan BMD, hibah merupakan salah satu sumber perolehan maupun pelepasan dari BMD sebagai bagian dari proses pemindahtangan. Persoalan ketiadaan dokumen kepemilikan atas pemindahtanganan BMD dalam bentuk hibah yang terjadi dimasa lampau memerlukan tindakan ekstra untuk menanganinya. Di satu sisi, kejadian tersebut terjadi di masa dimana belum ada aturan yang detail mengatur mengenai hibah. Namun di sisi lain, adanya dokumen kepemilikan/perolehan dari setiap BMD yang diperoleh dari APBD maupun dari hibah sangat diperlukan demi tertib pengelolaan BMD dan sebagai bentuk pengamanan terhadap BMD tersebut.

Kedua, pengawasan dan pengamanan yang kurang maksimal terhadap BMD rusak berat. Barang Milik Daerah jika dilihat dari proses dan tata acara perolehannya merupakan kekayaan daerah yang memang seharusnya mendapat pengawasan dan pengamanan secara baik. Sesuai dengan yang diungkapkan Riyono (2013) bahwa efektivitas pengelolaan barang/aset daerah juga ditentukan oleh efektivitas pengawasan dan pengendalian, di mana proses pengendalian dan pengawasan paling utama 
adalah pengendalian dan pengawasan oleh kepala SKPD. Perlakuan pengamanan harus sama antara BMD yang baik dengan BMD yang rusak ringan atau rusak berat. BMD yang rusak ringan ataupun yang rusak berat sebelum dilakukan penghapusan memiliki kapasitas yang sama dalam pengelolaan BMD hanya secara fungsi saja kurang bermanfaat. Tetapi jika lebih dicermati, walaupun sudah kurang bermanfaat secara fungsi namun tetap memiliki nilai ekonomi. Di sinilah pentingnya pengamanan, pengawasan serta perhatian extra terhadap BMD ini. BMD rusak berat harus segera ditindaklanjuti sebelum nilai ekonominya makin lama makin menurun. Jika pemeliharaan sudah tidak mungkin dilakukan lagi, salah satu langkah yang dapat diupayakan terhadap BMD rusak berat ini antara lain dengan pemindahtanganan dalam bentuk penjualan. Dengan langkah ini diharapkan akan ada pemasukan kas daerah dari hasil penjualan BMD rusak tersebut.

Ketiga, seringnya terjadi perpindahan kantor SKPD. Berdasarkan hasil riset, perpindahan kantor dari beberapa SKPD pada Pemerintah Kota Mataram juga menjadi penyebab dari banyaknya BMD rusak berat yang tidak diketahui secara fisiknya. Sejak memisahkan diri Pemkab. Lombok Barat, Pemerintah Kota Mataram memiliki kekurangan fasilitas bangunan tempat kerja untuk SKPD. Untuk menanggulangi hal tersebut, dilakukan proses pinjam pakai dari Pemerintah Provinsi NTB maupun Pemerintah Kabupaten Lombok Barat. Permendagri Nomor 19 Tahun 2016 menjelaskan bahwa pinjam pakai merupakan penyerahan penggunaan barang antara pemerintah pusat dan pemerintah daerah atau antar pemerintah daerah dalam jangka waktu tertentu tanpa menerima imbalan dan setelah jangka waktu tersebut berakhir akan diserahkan kembali.

Sampai dengan akhir tahun 2016 masih terdapat 7 (tujuh) SKPD yang status bangunan kantornya masih berstatus pinjam pakai sesuai dengan tabel 3. Selain bangunan kantor yang berstatus pinjam pakai, masih terdapat bangunan kantor SKPD yang berstatus sewa yakni bangunan kantor Badan Kepegawaian Daerah (BKD) Kota Mataram. Akibat bangunan tersebut bukan milik Pemkot Mataram maka menjadi tidak

Tabel 3. Daftar Objek Pinjam Pakai Pada Pemerintah Kota Mataram

\begin{tabular}{clll}
\hline No. & \multicolumn{1}{c}{ Nama Objek } & Kepemilikan & \multicolumn{1}{c}{ Keterangan } \\
\hline 1. & Dikpora Kota Mataram & Pemprov. NTB & Masih Dipergunakan \\
2. & Disbudpar Kota Mataram & Pemprov. NTB & Masih Dipergunakan \\
3. & Dinas Pertanian Kota Mataram & Pemprov. NTB & Masih Dipergunakan \\
4. & Dinas Pekerjaan Umum Kota Mataram & Pemprov. NTB & Masih Dipergunakan \\
5. & Dinas Dukcapil Kota Mataram & Pemkab. Lobar. & Dikembalikan tahun 2014 \\
6. & Dinas Kesehatan Kota Mataram & Pemprov. NTB & Dikembalikan tahun 2015 \\
7. & Dinas Koperindag Kota Mataram & Pemprov. NTB & Dikembalikan tahun 2015 \\
8. & Kantor Pemadam Kebakaran Kota Mataram & Pemprov. NTB & Masih Dipergunakan \\
9. & Kantor Persipda Kota Mataram & Pemprov. NTB & Masih Dipergunakan \\
10. & UPTD Pengujian Kendaraan Bermotor Dinas & Pemprov. NTB & Masih Dipergunakan \\
& Perhubungan Kota Mataram & & \\
\hline
\end{tabular}


mungkin untuk menempatinya secara terus menerus. Demi kelancaran operasional kegiatan SKPD kemudian banyak terjadi perpindahan kantor SKPD ke kantor baru yang sebelumnya telah dibangun oleh pihak Pemerintah Kota Mataram. Imbas dari perpindahan kantor ini berdasarkan hasil riset ini, banyak BMD rusak berat yang seharusnya masih menjadi tanggung jawab dari kepala SKPD selaku pengguna barang tidak ikut terbawa dikarenakan kondisinya sudah hancur dan lapuk. Hal ini yang memperparah kondisi yang terjadi pada penanganan BMD rusak berat. BMD rusak berat walaupun kondisi fisiknya sudah lapuk maupun hancur, jika belum dilakukan proses penghapusan maka BMD tersebut tetap masih menjadi tanggung jawab dari pengguna barang dan dan tanggung jawab administrasinya masih ada karena masih tercatat.

Keempat, sumber daya manusia (SDM) yang belum memadai. Sumber daya manusia selalu berkaitan dengan sebuah institusi atau organisasi. Sebuah institusi tidak akan dapat berjalan secara auto pilot, oleh karena itu sumber daya manusia akan selalu diperlukan sebagai perencana, pemikir dan penggerak untuk mencapai tujuan institusi tersebut. Hampir semua permasalahan yang dihadapi oleh sebuah institusi selalu erat kaitannya dengan sumber daya manusia. Pada Pemerintah Kota Mataram, sumber daya manusia juga dianggap sebagai salah satu kendala dalam penyelesaian penghapusan BMD rusak berat.

Hasil riset ini mengungkapkan bahwa kendala kekurangan staf tersebut akibat kesulitan untuk menarik/memutasikan pegawai dari SKPD lain. Kekurangan staf pada
BPKAD Kota Mataram khususnya pada bidang aset juga disebabkan karena tidak adanya pelimpahan personil dari Bagian Umum Setda Kota Mataram ketika BPKAD Kota Mataram baru terbentuk. Pegawai dengan kualifikasi tertentu apalagi jika memiliki kinerja yang baik pada umumnya akan dipertahankan oleh SKPD asalnya. Pengelolaan BMD pada tataran SKPD belum dianggap penting dan strategis, oleh karena itu penugasan pegawai yang menjadi Pengurus Barang belum mempertimbangkan kompetensinya dan masih asal "comot". Ditambahkan juga bahwa seringnya pergantian Pengurus Barang pada SKPD menyebabkan kurangnya kemampuan Pengurus Barang yang baru untuk menyelesaikan tugasnya.

Kendala pada SKPD didominasi oleh kurangnya kualitas pegawai yang ditunjuk sebagai Pengurus Barang. Berkaitan dengan hal tersebut, langkah yang ditempuh Pemerintah Kota Mataram sudah berada pada jalur yang tepat. Demi mengantisipasi permasalahan tersebut terulang di masa yang akan datang, BPKAD Kota Mataram telah melakukan upaya dalam bentuk kegiatankegiatan peningkatan kapasitas aparatur dalam ruang lingkup pengelolaan BMD. Kegiatan tersebut berupa bimbingan teknis maupun sosialisasi peraturan mengenai pengelolaan BMD yang ditujukan kepada semua pelaksana kegiatan pengelolaan BMD meliputi Pengguna Barang maupun Pengurus Barang pada SKPD. Kegiatan-kegiatan yang dilakukan tersebut menunjukkan bahwa BPKAD Kota Mataram memiliki komitmen yang kuat dalam melakukan pembenahan pengelolaan BMD pada Pemerintah Kota Mataram. 
Kelima, tidak adanya Standar Operasional Prosedur (SOP) yang mengatur mengenai pelaksanaan penghapusan BMD rusak berat. Kendala lain menjadi penghambat dalam proses penghapusan $B M D$ rusak berat ini yakni belum adanya SOP yang dibuat. Standar Operasional Prosedur (SOP) dapat dikatakan sebagai pola/alur dari tahapan-tahapan proses yang harus diikuti untuk mencapai suatu tujuan yang diinginkan. Pada organisasi sektor publik, pola dari tahapan-tahapan tersebut tentunya harus mengacu pada peraturan perundangundangan yang berlaku. Demikian halnya pada pengelolaan BMD pada umumnya dan khususnya proses penghapusan BMD, adanya Standar Operasional Prosedur (SOP) dapat dijadikan sebagai alat untuk mengukur kinerja para pelaksana pada proses penghapusan $\mathrm{BMD}$, memperjelas tugas, wewenang dan tanggungjawab para pelaksana pada proses penghapusan BMD serta meningkatkan efisiensi serta efektifitas pelaksanaan kegiatan tersebut. Ketiadaan SOP dapat menyebabkan rancunya kegiatan yang akan dilakukan. Pengurus barang di level SKPD juga selama ini hanya menunggu perintah yang diberikan oleh BPKAD tanpa mengetahui tahapan-tahapan yang seharusnya menjadi wewenang dari Pengurus Barang atau Pengguna Barang sebagai atasannya langsungnya.

\section{SIMPULAN}

Penghapusan BMD merupakan tindakan terakhir yang harus ditempuh Pemerintah Daerah dalam menindaklanjuti BMD dengan kondisi rusak berat. Sebagai salah satu unsur dari sistem pengelolaan Barang Milik Daerah, penghapusan BMD memiliki peranan yang penting dalam terlaksananya tata kelola yang baik dan teratur. Keteraturan penghapusan BMD dapat menjadi indikator bahwa BMD sebagai sarana penunjang pemerintah dalam melakukan pelayanan kepada masyarakat telah dikelola secara optimal.

Berkaitan dengan riset ini, kesimpulan yang diperoleh peneliti yaitu Pelaksanaan penghapusan BMD rusak berat pada Pemerintah Kota Mataram dengan jumlah sebanyak 8.241 item barang senilai $\mathrm{Rp}$. $36.624 .708 .803,49$ belum dapat diselesaikan secara tuntas dan masih dalam tahapan uji fisik. Proses penghapusan BMD merupakan tahapan terakhir dari proses pemindahtangan BMD atau proses pemusnahan BMD sebagai satu rangkaian proses. Tahapan-tahapan yang dilakukan sudah selaras dengan tahapan-tahapan yang diatur melalui Permendagri Nomor 19 Tahun 2016, namun pelaksanaannya masih dipusatkan pada BPKAD Kota Mataram sehingga tahapan uji fisiknya memerlukan waktu yang lama karena dilakukan atas seluruh usulan penghapusan BMD rusak berat pada semua SKPD pada Pemerintah Kota Mataram. Secara umum permasalahan utama yang dihadapi adalah ketidaklengkapan dokumen kepemilikan/ perolehan dan ketidakjelasan fisik dari BMD yang diusulkan untuk dihapuskan. Permasalahan tersebut terjadi karena disebabkan hal-hal sebagai berikut: 1). Proses hibah di masa lalu yang tidak disertai dokumen kepemilikan/perolehan; 2). Pengawasan dan pengamanan yang belum maksimal terhadap BMD dengan kondisi rusak berat; 3). Seringnya terjadi perpindahan kantor SKPD; 4). Sumber Daya Manusia (SDM) yang belum memadai; dan 5). 
Tidak ada Standar Operasional Prosedur (SOP) tentang penghapusan BMD.

\section{DAFTAR PUSTAKA}

Asmony, T. (2015). Penelitian Kualitatif Pendekatan Studi Kasus. Mataram University Press.

Aziz, K.F. (2015). Evaluasi Implementasi Penghapusan Aset Tetap Studi Pada Pemerintah Kabupaten Gunung Kidul. Tesis. Universitas Gadjah Mada.

Batubara, A.H. (2006). Konsep Good Governance dalam Konsep Otonomi Daerah. Jurnal Analisis Administrasi Publik, 3(1), 1-6.

Blaikie, N. (2000). Designing Social Research: The Logic of Anticipation. Cambridge: Polity Press.

Fransiska, F.T. (2014). Pelaksanaan Penghapusan Barang Milik Daerah Berdasarkan Peraturan Menteri Dalam Negeri Nomor 17 Tahun 2007 Tentang Pedoman Teknis Pengelolaan Barang Milik Daerah. Malang: Universitas Brawijaya. Diakses dari http://hukum.studentjournal.ub.ac.id/in dex.php/hukum/article/view/520/508

Hamdani. (2015). Kesiapan Pemda dan BLUD Dalam Implementasi Akuntansi Berbasis Akrual dan Evaluasi. Diakses dari http://keuda.kemendagri.go.id/pages/vi ew/26-materi-paparan pada tanggal 23 November 2016.

Hariyono, A. (2007). Prinsip dan Tekhnik Manajemen Kekayaan Negara. Diakses dari

http://www.bppk.kemenkeu.go.id/publi kasi/artikel/149-artikel-kekayaannegara-dan-perimbangan-keuangan pada tanggal 20 November 2016.

Hasni, J.A. (2012). Evaluasi Sistem dan Prosedur Penghapusan Barang Milik Daerah (Studi Kasus Pada Bagian Aset
Setda Kabupaten Lombok Tengah). Tesis. Universitas Gadjah Mada.

Kamayanti, A. (2016). Metodologi Penelitian Kualitatif Akuntansi. Jakarta: Yayasan Rumah Peneleh.

Langelo, F., Saerang, D.P.E., \& Alexander, S.W. (2015). Analisis Penerapan Standar Akuntansi Pemerintahan Berbasis Akrual Dalam Penyajian Laporan Keuangan Pada Pemerintah Kota Bitung. Jurnal EMBA, 3(1), 1-8.

Miles, M.B. \& Huberman, A.M. (1992). Analisa data kualitatif. Jakarta: Universitas Indonesia (UI-Press).

Peraturan Pemerintah No. 6 Tahun 2006 tentang Pengelolaan Barang Milik Negara/Daerah.

Peraturan Pemerintah No. 71 Tahun 2010 tentang Standar Akuntansi Pemerintahan.

Peraturan Pemerintah No. 27 Tahun 2014 tentang Pengelolaan Barang Milik Negara/Daerah.

Peraturan Menteri Dalam Negeri No. 17 Tahun 2007 tentang Pedoman Teknis Pengelolaan Barang Milik Daerah.

Peraturan Menteri Dalam Negeri No. 64 Tahun 2013 tentang Penerapan Standar Akuntansi Pemerintahan Berbasis Akrual Pada Pemerintah Daerah.

Peraturan Menteri Dalam Negeri No. 19 Tahun 2016 tentang Pedoman Pengelolaan Barang Milik Daerah.

Riyono, S. (2013). Pemanfaatan Aset Daerah (Studi Tentang Pola Kemitraan Aset Tanah Pemerintah Provinsi Jawa Timur). Jurnal Administrasi Publik, 11(2), 237245.

Shabrina, K.N. (2014). Efektifitas Pengamanan Aset dalam Mewujudkan Akuntabilitas di Pemerintah Kota Surabaya. Jurnal Kebijakan dan Manajemen Publik, 2(1), 1-9. 